\title{
Economic Performance Through the Surplus Account Method With the Maghreb Railway Companies as Case Study
}

\author{
Augustin Mapapa Mbangala \\ Kinshasa Higher Institute of Commerce \\ Achraf Tarsim \\ African Development Bank Group
}

This paper focuses on the assessment of the economic performance of three railway companies from Maghreb countries using the Surplus account Method. This method shows the role of these public enterprises in the production and distribution of added value. The analysis allows to identify the, positive or negative, contribution of each production factor to productivity growth. At the same time, it shows which partners benefit from the added value created by these companies.

Keywords: Maghreb railway companies, economic efficiency, surplus account method

\section{INTRODUCTION}

Generally, a company's economic performance is measured from accounting data using the economic profitability ratio. This can be obtained by determining the ratio between total earnings before interest and taxes (EBIT) and capital invested. In doing so, this approach is positioned in neo-classical economic theory, which emphasizes the investor's objective for maximizing profits. This vision of performance limits the company to a single stakeholder, who is the shareholder, and gives the impression that the company exists first and foremost to achieve the latter's objective (Nizet and Pichault 2007).

However, the performance of a company as an economic entity must be analyzed with respect to the three main functions of any economic activity: production, distribution, and supply. As a productive entity, the organization seeks to combine all the factors of production in the most efficient way possible (Estache and al., 2006). In its distribution function, the company makes its product available to the market at a given price. Taking into consideration the constraints of production, the supply function, on the other hand, consists of remunerating all the economic actors who contribute to production (managers and employees, suppliers, lenders, shareholders, the State, etc.). All this indicates that the evaluation of the economic performance of an organization must logically integrate the analysis of the conditions under which it creates and distributes the product among the agents who have contributed to it (Plane 1999, Rivera-Trujillo 2005).

Analysis based on the surplus account method appropriately responds to this concern. By definition, the surplus accounts method is an accounting construction that makes it possible to assess, over time, the variation in a firm's overall productivity and the distribution of this variation in productivity to the benefit or detriment of the firm's various partners. In doing so, the method has at least a twofold interest: it allows 
for the analysis of overall productivity on the one hand; and provides a global vision of the organization as a unit of value creation and distribution on the other hand.

The use of this method has yielded excellent results in the case of EDF (Electricite de France) (Lecomte and Louis 1974, Lauzel and Teller 1997). Its use is more justified in public enterprises, as in the case of the Maghreb railway companies that are the subject of this study (Grifell - Tatjé and Lovell 2006). Indeed, the public authorities assign multiple and conflicting objectives to these companies: balancing management and fulfilling the public service mission. Thus, their evaluation must objectively consider both economic and social criteria.

The work is structured in five points. After having introduced the analysis in the first point, the methodological approach is explained in the second point. The third point presents a brief inventory of the Maghrebi railway companies. The results obtained as well as the analyses carried out will be presented in the fourth point. The last point summarizes the conclusions and recommendations derived from this analysis.

\section{Methodological Approach}

The surplus account method allows us to understand the company in its dual function of wealth creation and distribution (CERC 1980). Wealth creation is obtained when, from one year to the next, the same levels of factors produce more output, or when the production supplement is greater than the factor supplement consumed, both expressed in monetary value and at the price of a base year. In this case, the company is said to have achieved technical productivity gains or created wealth. Mathematically, the aggregate productivity surplus is obtained by getting the difference between the variation in the quantities produced and the variation in the quantities of productive factors used from one year to the next (Vincent 1971). The equation that defines the formation of the surplus $(\sigma)$ can be formalized as follows:

$\sigma=\sum_{i=1}^{I} p_{i} \Delta q_{i}-\sum_{j=1}^{J} d_{j} \Delta k_{j}$

with,

$p_{i} \quad:$ Product prices $(i=1, \ldots, I)$ corresponding to the first of the two years,

$\Delta q_{i} \quad$ : Variation in quantity produced between the two years under consideration, $\left(t\right.$ and $\left.t_{+1}\right)$,

$d_{j} \quad$ : Price of the factors of production $(j=1, \ldots, J)$ corresponding to the first of the two years,

$\Delta k_{j} \quad$ : Variation in the quantity of the factor used between the two years under consideration. ( $t$ and $\left.t_{+1}\right)$.

We speak of an overall gain in productivity when the surplus is positive, and of a loss when it is negative.

In order to eliminate the firm size "effect" and at least allow an evolutionary comparison between firms belonging to the same sector, the surplus, expressed in monetary value, can be related to the firm's output amount during the first year to provide an indicator expressed in relative value.

The distribution of the wealth generated occurs automatically among stakeholders when product and factor prices vary from one year to the next. Concretely, the overall effect of price changes is measured by taking for each item of the operating account (income and expenses), the price variation from the year $t$ to the year $t_{+1}$, weighted by the quantity produced during the second year. Here, we therefore take into consideration constant quantities.

Therefore, the surplus to be shared $(\alpha)$ consists of the amount in the surplus generated within the company, and the external surplus, generated from external agents from one year to the next. It will therefore be determined by the following expression:

$\alpha=\sum_{i=1}^{I}\left(-\Delta p_{i}\right)\left(q_{i}+\Delta q_{i}\right)+\sum_{j=1}^{J}\left(\Delta d_{j}\right)\left(k_{j}+\Delta k_{j}\right)$ 
We will refer to as "advantage", the additional values obtained due to price variations, by the buyers of the company's products or by the economic agents who provide it with its factors of production. Therefore, an increase in the price of an item:

- is an advantage for the supplier and a disadvantage for the company, if this article is a production factor for the latter,

- is an advantage for the company and a disadvantage for the customer, if this article is a finished product of the company.

Ultimately, we will note that the sum of the distributed benefits is equal to the overall productivity surplus due to the accounting equality that is established in the income statement (after calculating the net income for the period)

$\sum_{i=1}^{I} p_{i} q_{i}=\sum_{j=1}^{J} d_{j} k_{j}$

The income statement of railway companies ${ }^{3}$; the input/data necessary for applying the surplus method, is composed of different items of income and expenses, each reflecting the relationship between the company and a specific economic agent. As a result:

- revenue from freight traffic is referred to freight customers,

- revenue from traveler traffic is referred to traveler users,

- $\quad$ other operating revenues is referred to other customers,

- financial income gives an idea of the financial participation,

- external expenses reflect the company's suppliers and subcontractors,

- personnel expenses refer to the company's employees,

- depreciation and amortization refer to the physical capital used,

- financial charges refer to banks,

- the result for the year reflects the State remuneration.

For the railway companies in Morocco and Algeria, we used the three income statements, namely the operating income statement, the financial income statement, and the extraordinary income statement. For the Tunisian railway company, the financial income statement does not appear in the calculations of the surplus account for reasons of data availability.

Applying this method to the Maghrebi railway companies required the consideration of certain assumptions such that income and expenses can be disaggregated in the income statement in quantity and price. For the three companies, the first modification consisted in the aggregation of exceptional income and expenses respectively with other operating income and external operating expenses. This assumption is justified by the fact that exceptional income and expenses generally represented insignificant amounts and therefore, for reasons of clarity, we deemed this aggregation useful. This is further justified by the fact that the disaggregation of these various items in terms of quantity and price uses the same index.

To apply the method, we need price and quantity data for each item on the income statement. To disaggregate traveler and freight revenues, we used the traveler-kilometer and ton-kilometer indicators, respectively, to obtain the average unit price for each of these activities. Similarly, we used the number of staff to break down the personnel expenses item to obtain the unit wage cost (Gathon 1986, Mbangala 2001).

The disaggregation of the items "other operating income" and "external expenses" into quantity and price required the use of the consumer price index. Indeed, in the railway activity, these items are composed of different types of upstream and downstream elements. Upstream, we find, for example, the purchase of fuel (the main item of external charges), various materials and supplies, maintenance, and repair equipment, etc. In addition, there is the purchase of equipment and materials, which is the main item of external charges. Downstream, catering, hotels and rental income are examples of the various services provided by railway companies. Thus, the consumer price index adequately reflects the average price of these various products and expenses. 
In the same vein, we have used the industrial production price index to split the "depreciation allowances" item into quantity and price. In doing so, we considered that the consumption of capital refers mainly to fixed railway assets (stations, tracks, rolling stock). Thus, the industrial producer price index is an appropriate indicator of the average price of durable assets.

The financial proceeds of the Maghrebi railway companies mainly come from bank interest income, and to a certain extent from income from financial fixed assets. On the other hand, their financial expenses are mainly made up of debt charges contracted with banks to finance their investments. Consequently, the use of the average market interest rate proved necessary to disaggregate these two financial items in terms of quantity and price.

\section{The Maghrebi Railways}

As in most part of Africa, transport organization and policy in North Africa is the responsibility of the state via the central government. Indeed, in Morocco, it is the Ministry of Transport and Equipment, which oversees all modes of transport. On the other hand, in Algeria and Tunisia, the responsibilities for transport infrastructure and services are dissociated between several ministries.

Since the beginning of the 2000s, the political authorities in North Africa have organized themselves towards creating modalities for the implementation of a common transport action program aimed at improving existing transport systems, in order to move toward an integrated system. This ambitious project is being carried out under the impetus of the Arab Maghreb Union (AMU) and other institutional initiatives such as that of the Euro-Mediterranean Conference of Ministers of Transport. In this context, since the late 1990s, governments have begun to undertake far-reaching reforms at all levels of the transport sector. In the rail transport sector, the fundamental issues of this transformation concern the separation of operations and infrastructure and the involvement of the private sector in the activity. However, the nature and dimension of these reforms vary from country to country and their effective implementation is not yet complete.

Tunisia is at the beginning of a reform that consists mainly in giving a large administrative and financial autonomy to the railway company SNCFT (Société Nationale des Chemins de Fer Tunisiens). This reform advocates the establishment of a structure ready to consider private participation in the railway sector. Unlike Tunisia, Morocco and Algeria are quite advanced in their reform process: the separation of infrastructure management and operations is effective in various forms. Thus, a legislative framework is already in place to allow limited private sector participation in the construction and/or operation of railways. Indeed, Algeria intends to open rail transport to the private sector under the concession regime. This opening is justified by the fact that the State monopoly has led to a constant decrease in the performance of this mode of transport and a systematic recourse to the public treasury for its financing. The private sector will be responsible for the rehabilitation and development of the rail network. The Moroccan National Railways (ONCF, Office National des Chemins de Fer du Maroc), which operates as a commercial and industrial public establishment, is governed by an institutional framework that is being overhauled in accordance with the new policy aimed at increasing the competitiveness of rail transport and reducing and rationalizing financial transfers from the State to the sector. The implementation modalities of this policy consist in the liberalization of traveler and goods rail transport tariffs (which took place in 2002) and the granting of an operating concession to ONCF. While awaiting the introduction of the public-private partnership (PPP), the management method adopted is based on the signing of a contract - a program governing relations between the State and the railway company. The plan contract signed for the period 2002-2005 aims at improving the company's situation and modernizing its management methods. The State undertook to grant capital endowments over a determined period; to grant ONCF freedom in terms of tariffs and to provide the office with the benefits of all financing operations necessary for the realization of its investment program; with the State standing as a guarantor whenever one is required from the Office by the funders. Despite this process of restructuring the railway sector, no legislative reform is yet envisaged in these countries with regards to market coordination and the creation of a regulatory body for the railway sector.

The specialization of railway companies in freight transport, a common feature of the African rail sector, is also true for the three Maghrebi companies under consideration. Indeed, the share of freight in 
relation to the total traffic units represents $68.9 \%$ for ONCF, $62.7 \%$ for SNCFT and $65.5 \%$ for SNTF (Société Nationale de Transport Ferroviaire d'Algérie). Phosphate is the principal material among the different goods that the companies transport. This can be explained by the first objective motivating the construction of railways in Africa during the colonial period, which was, the transport of raw materials from inland to seaports. Traveler transport, subdivided into long distance and suburban transport, has different level of importance in the three companies. ONCF is the only company that has recorded an increasing share of traveler transport compared to that of goods. This can be explained by the improvement of the services offered by this company, by the significant investments in modernizing rail infrastructure and traveler reception, but also by the pricing flexibility that the Moroccan government grants to ONCF. This flexibility remains limited in Algeria and Tunisia, where prices are administered by the central authority, with periodic revisions subject to political rather than economic factors.

\section{Surplus of Productivity and Its Distribution Among Economic Agents}

The application of the surplus method to the three Maghrebi railways, using time series of income statements over the period 1998-2006, allows for the determination of the overall factor productivity surplus generated. This approach also makes it possible to determine the distribution of this surplus among the various economic agents operating in the railway sector. This redistribution of the wealth created is subject to various changes that the sector has undergone, particularly in terms of pricing policies, activity specialization and human resource policies.

In general, ONCF achieved overall factor productivity gains between 1998 and 2006, except for the 2002-2003 period (Figure 1). Over the period of the study, the company achieved an average productivity gain of $4.37 \%$. This overall positive result is thanks to the fact that the quantities produced increased more than proportionally to the quantities of production factors used in the activity, particularly in 2004-2005.

The overall average factor productivity surplus achieved by SNCFT in Tunisia was $6.42 \%$ between 1998 and 2006. At the beginning of the 1998-1999 period, SNCFT recorded a productivity loss of 12.49\%; the situation improved during the rest of the period, particularly in 2005-2006, as shown in Figure 1. However, the results show that this surplus is thanks to the fact that the decline in production factors was more than proportional to that of production output. Using the 2005 - 2006 period as an example, it can be noted that the number of its staff decreased substantially while it continued to produce as much, if not slightly more.

The situation of SNTF in Algeria is quite special. From one year to the next, we saw strong variations, sometimes positive, sometimes negative, in overall factor productivity, resulting in an average productivity gain close to zero between 1998 and 2006. Depending on the period, we may find ourselves in a situation where variations in factor quantities are substantially greater than variations in production or vice versa. These variations are mainly due to other operating income and external expenses; items containing heterogeneous elements that are difficult to explain.

The different policies for financial consolidation and modernization of the railway sector in Maghreb have had varying effects depending on the country. While Morocco and Tunisia recorded surpluses in their overall factor productivity averaging 4.37\% and 6.42\% respectively between 1998 and 2006, Algeria did not achieve such results. This finding is in line with the observations of sector experts highlighting the very flexible budgetary constraints of the SNTF, which have not helped achieve the expected results of the policies put in place. 


\section{FIGURE 1 \\ VARIATIONS IN THE OVERALL PRODUCTIVITY SURPLUSES 1998 - 2006}

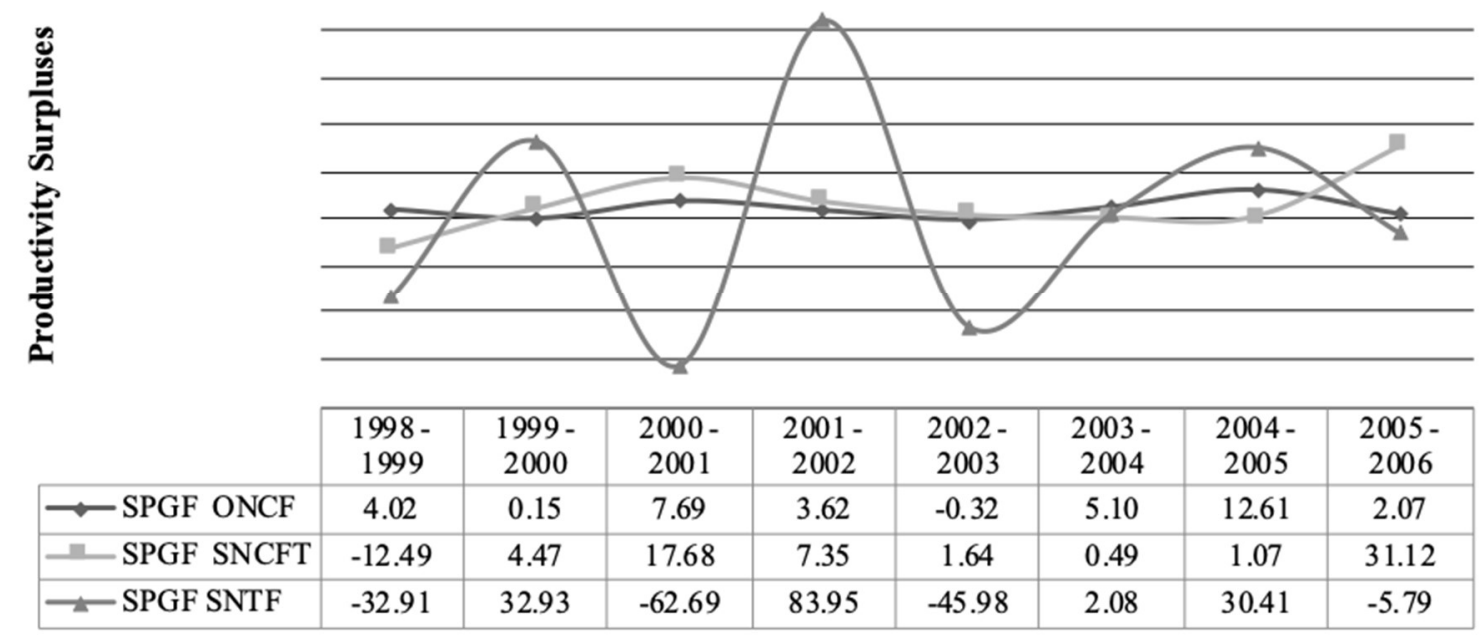

The surpluses or losses generated by the total factor productivity (TFP) are distributed differently among the different economic agents in the three Maghrebi countries under consideration.

In Morocco, the wealth generated by ONCF does not benefit the company's freight and traveler customers, as illustrated in figure 2. Throughout the period, freight tariffs increased more than proportionally to the quantities transported. With the liberalization of tariffs that took place in 2003, there was a significant increase in the price of freight transport. As a result of the significant investments made since 2000, leading to an improvement of the operating conditions in traveler activity, an increase in demand, and thus in production, was observed that was greater than the increase in prices offered to travelers. Even if the users are not directly benefiting from the surplus, it can be said that their situation is improving from one year to the next.

The main beneficiaries of the wealth generated by ONCF between 1998 and 2006 are suppliers, staff and above all the State. Indeed, the continuous reduction of the number of staff was less than the increase in employee salaries, thus allowing the staff to benefit from the surplus generated. The strategy put in place by the State to clean up ONCF's finances has been beneficial by allowing the company to improve its positive net result from one year to the next.

Travelers and companies transporting their goods by rail in Tunisia are at a disadvantage because prices have risen more sharply than the increase in production. The approval of prices by the supervisory ministry does not improve the situation of travelers insofar as the annual increase in prices is more than proportional to demand. Thus, this price administration policy, aimed at increasing demand, fails to achieve its objectives. Moreover, the results show that SNCFT employees have benefited greatly from the advantages generated by the productivity surpluses (figure 2). Indeed, the workforce was divided by 3 and the salary quadrupled over this period. The Tunisian State, owner of SNCFT, does not ultimately reap the benefit from the effort put in place to improve the company's situation.

Algeria's case is special, in fact, during the periods when SNTF had surpluses, the benefits mainly went to the State and then to the staff (figure 2). This logic remains valid for periods when heavy losses were recorded, the State assumed the burden. Travelers and freight customers do not benefit from gains due to changes in total factor productivity. This is probably due to the lack of flexibility in the setting of prices in Algeria. The customers of the Maghrebi railway companies (traveler and freight activities) have, in general, hardly benefited from the surpluses created by total factor productivity. The continuous increase in prices, which is higher than that of quantities, explains this distortion in the distribution of wealth. Thus, whatever the method of price setting, whether by market mechanisms as it is in Morocco, or by approval of prices by the regulatory authorities as it is in Tunisia and Algeria, customers do not benefit from the situation. This 
observation clearly demonstrates that the competitiveness of railways and the increase in demand for them depends not only on pricing but also on the quality of the services offered.

The policy of rationalization of human resources has been accompanied, in the three North African companies, by a greater increase in wages. The employees are therefore the greatest beneficiaries of these companies' surpluses.

FIGURE 2

DISTRIBUTION OF THE SURPLUS AMONG ECONOMIC AGENTS

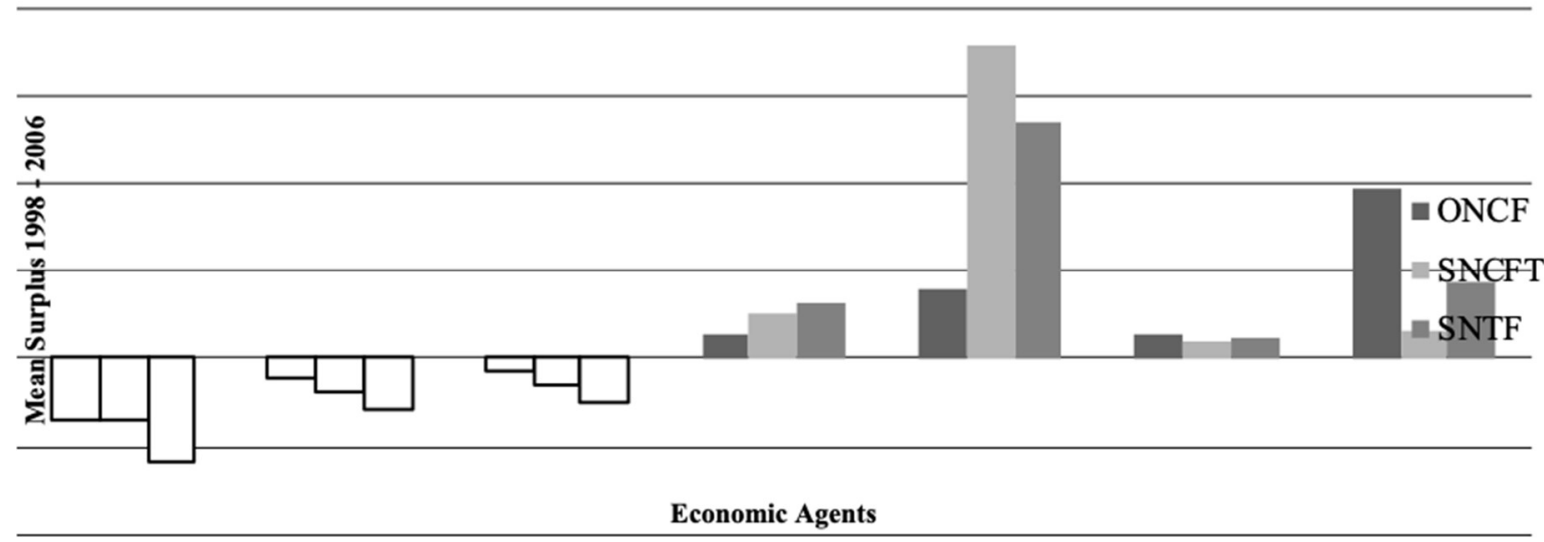

\section{CONCLUSION}

The use of the surplus method, combining the accounting data of operating results and physical data of the activity, to the railway companies in Morocco, Tunisia and Algeria, shows that the implementation of strategic plans aimed at improving and modernizing this sector have led to differentiated results.

Indeed, the price control and administration policy put in place by SNCFT and SNTF has neither improved the situation of customers, travelers, and companies, nor has it increased the demand for rail transport. On the other hand, the setting of prices, through market mechanisms coupled with appropriate investments to improve the quality of services in Morocco, has enabled railway users to gradually benefit from the wealth created and to increase their demand for rail transport. This clearly demonstrates that price interventionism can only be an effective measure if it is part of a more comprehensive strategy. Similarly, the policies of restructuring and upgrading of the human resources invested by the three companies have led to improved productivity and have fully benefited the staff.

Nevertheless, it is important to report that the overall picture is rather positive, as the companies have recorded average increases in their total factor productivity, thus enabling them to clean up a previously critical financial situation. However, these results cannot be achieved if the budgetary constraints imposed on companies remain loose, even by implementing the most elaborate strategies as was the case in Algeria.

\section{ACKNOWLEDGEMENT}

Translated \& edited by American Publishing Services (https://americanpublishingservices.com/). 


\section{REFERENCES}

Cerc. (1980). Productivité globale et comptes de surplus. Document du CERC (Centre d'Etudes des Revenus et des Coûts), 55/56.

Estache A., Perelman S., \& Trujillo L. (2006). Infrastructure Reform in Developing Economies: Evidence from a Survey of Economic Performance Measures. In T. Coelli \& D. Lawrence (Eds.), Performance Measurement and Regulation of Network Utilities (pp. 133-174). Northampton, MA, USA: Edward Elgar.

Gathon, H.J. (1986). Productivité globale et comptes de surplus: Le cas de seize compagnies de chemin de fer. Annales d'Economie Publique, Sociale et Coopérative, 57.

Grifell-Tatjé, E., \& Lovell, C.A.K. (2006). Productivity at the Post: its Drivers and its Distribution, Working Papers Series, 2. Centre for Efficiency and Productivity Analysis.

Lauzel, P., \& Teller, R. (1997). Contrôle de gestion et budgets (Sirey $8^{\text {ème }}$ edition).

Mbangala Mapapa, A. (2001, June). L'évaluation de la performance économique des entreprises publiques africaines par la méthode des comptes de surplus. Annals of Public and Cooperative Economics, 72(2).

Nizet, J., \& Pichault, F. (Eds.). (2007). Les performances des organisations africaines. Pratique de Gestion en Contexte Incertain (pp. 7-17). Editons L'Harmattan.

Plane, P. (1999). Privatization, technical efficiency and welfare consequences: The case of the Cote d'Ivoire Electricity Company. World Development, 27(2), 343-60.

Rivera-Trujillo, C. (2005). Measuring efficiency in North and South American railways using a stochastic frontier model: An international comparison. In D. Hensher (Ed.), Competition and Ownership in Land Passenger Transport (pp. 423-42). Elsvier.

Vincent, A. (1971). Indices et surplus de productivité globale. Etude méthodologique comparative. Revue Economique, XXII(1), 1-42. 


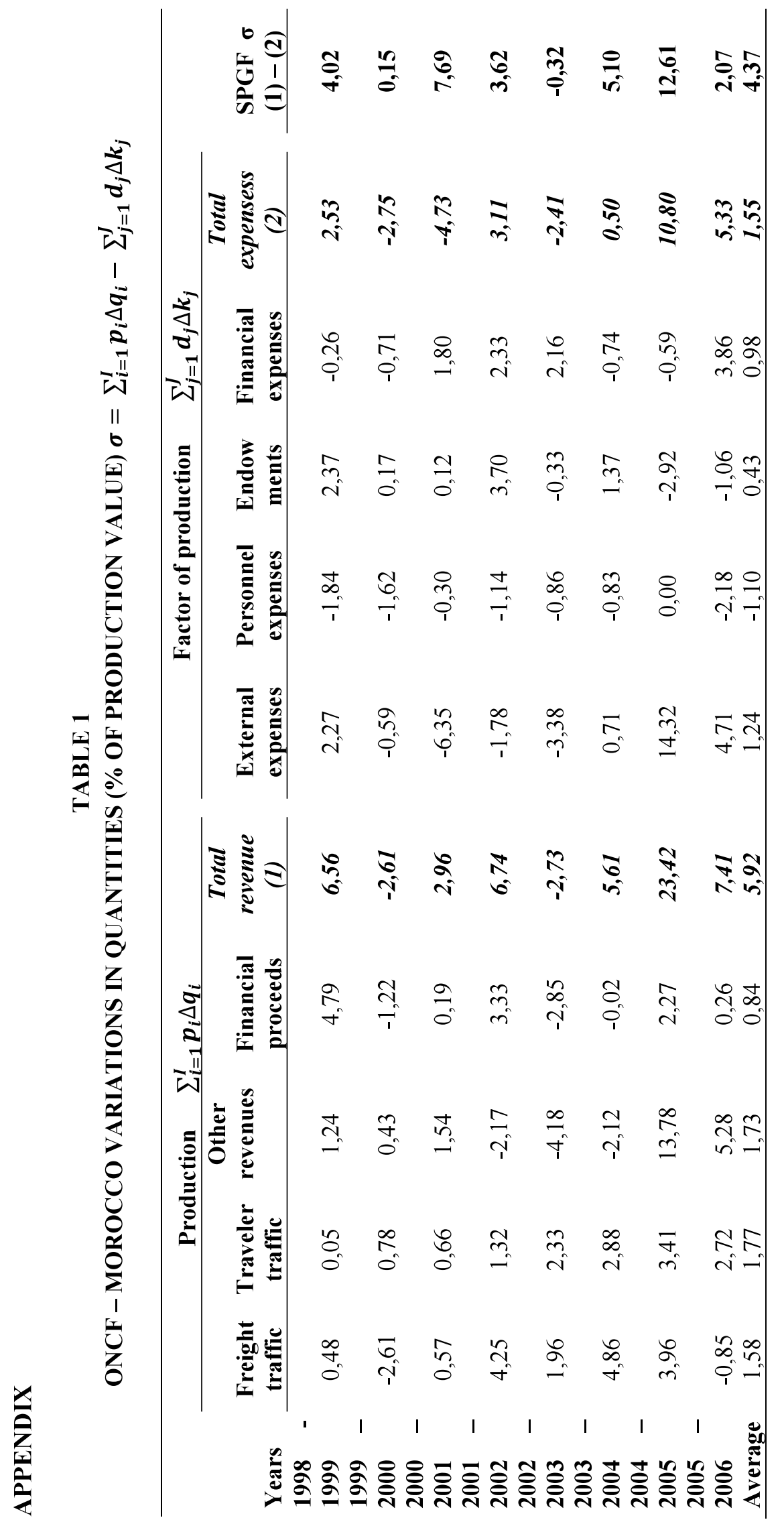




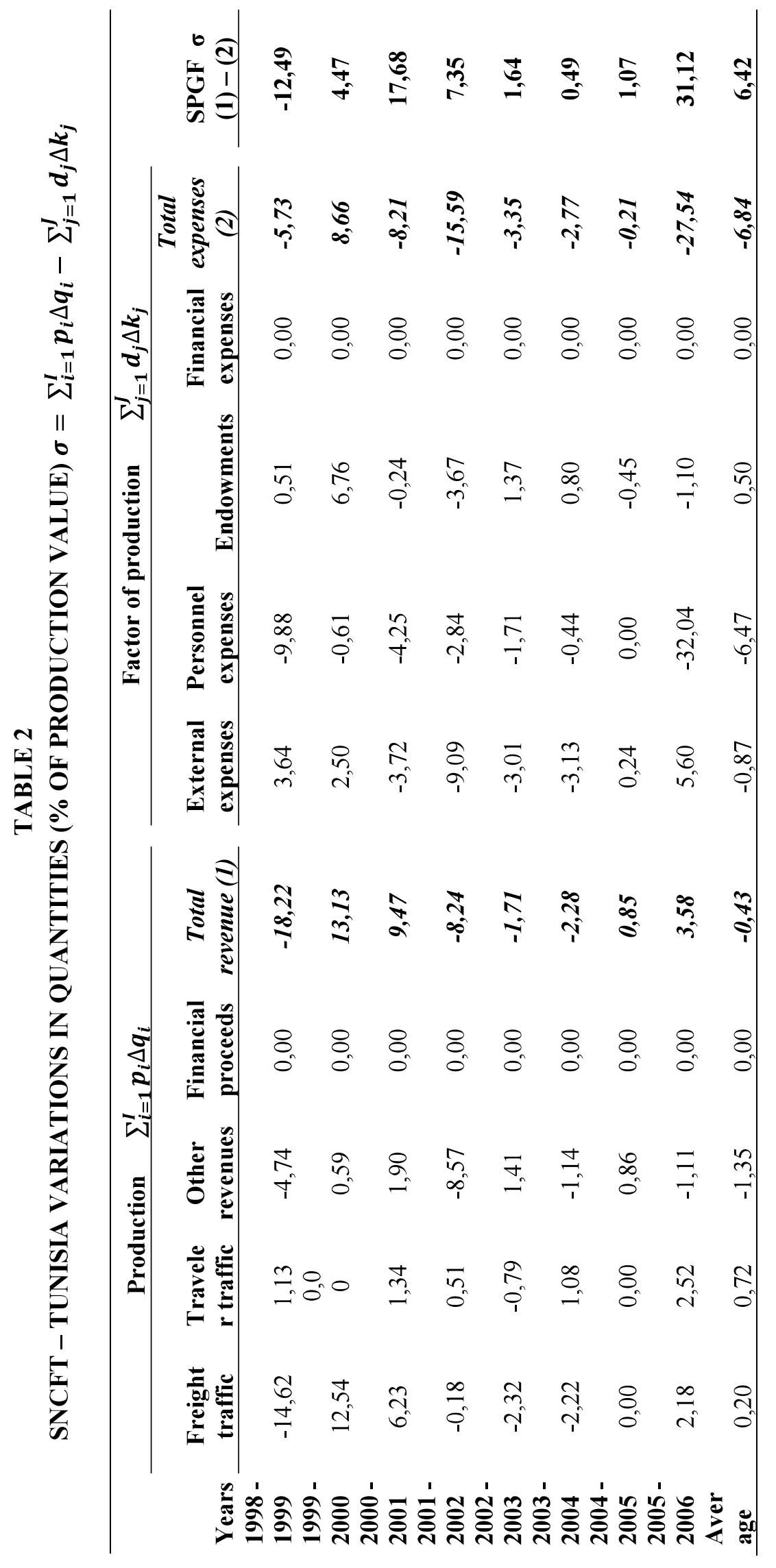

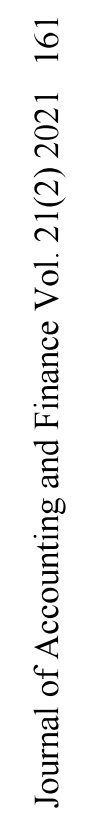




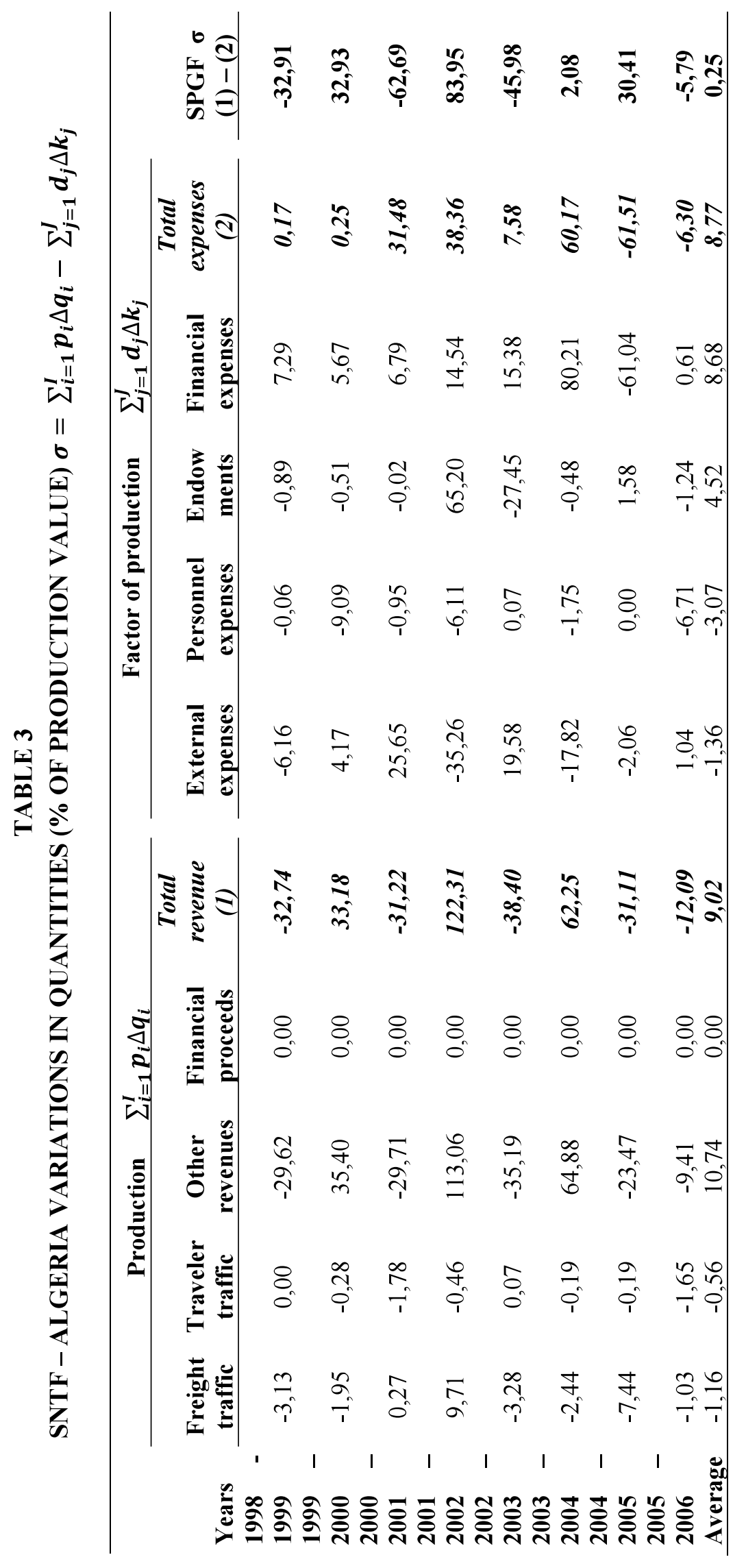




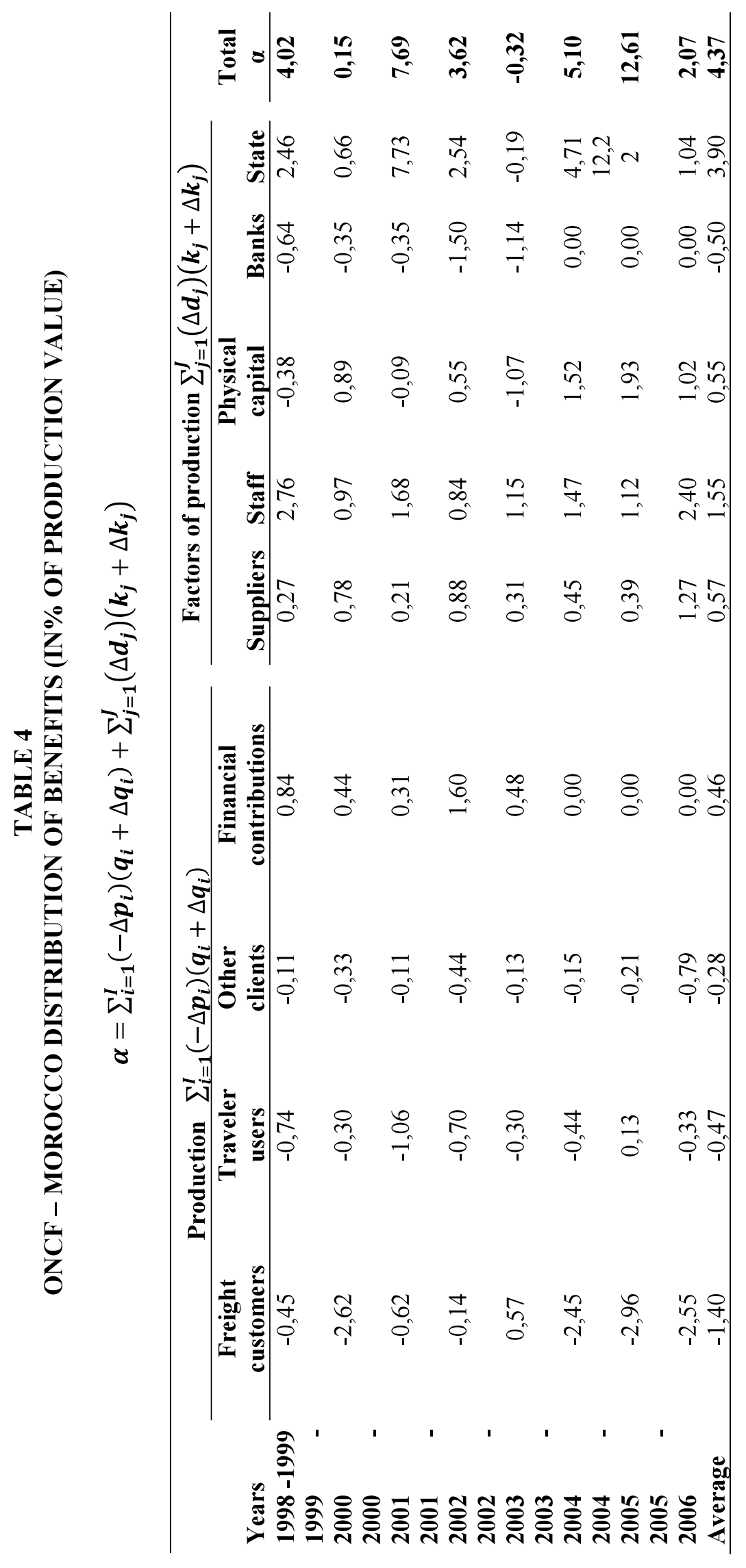

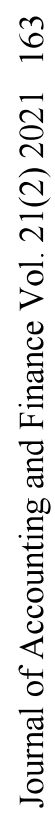




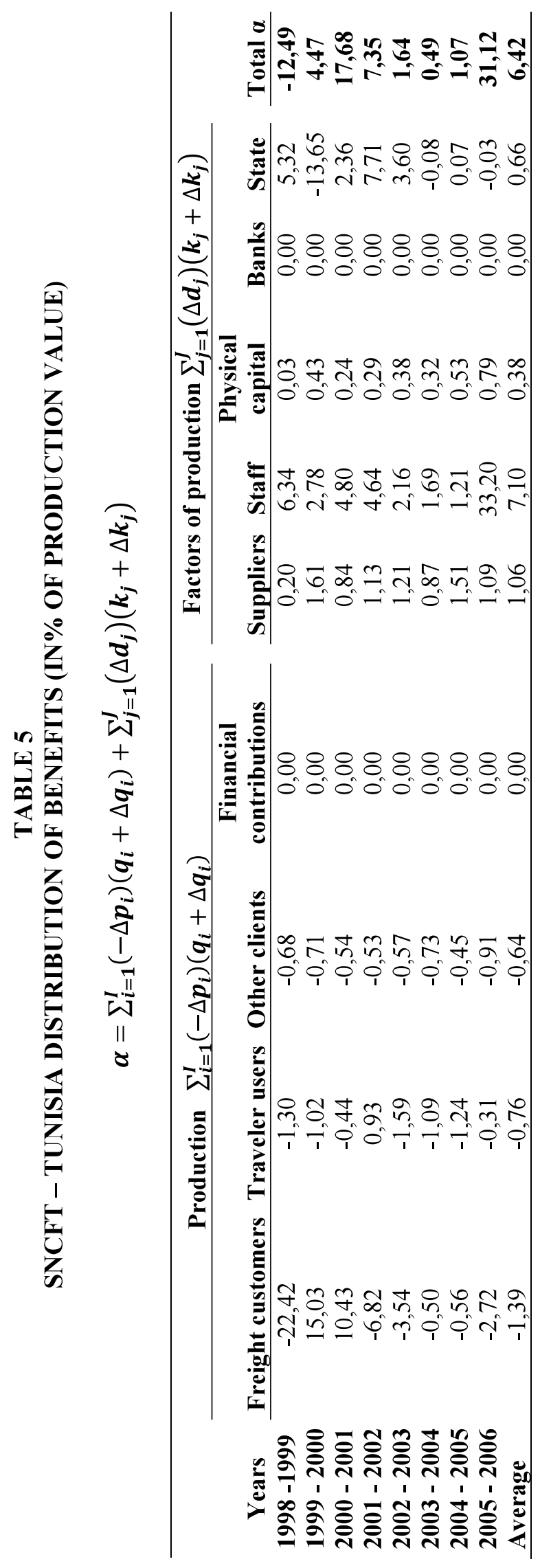

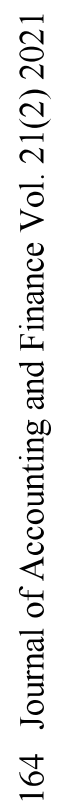




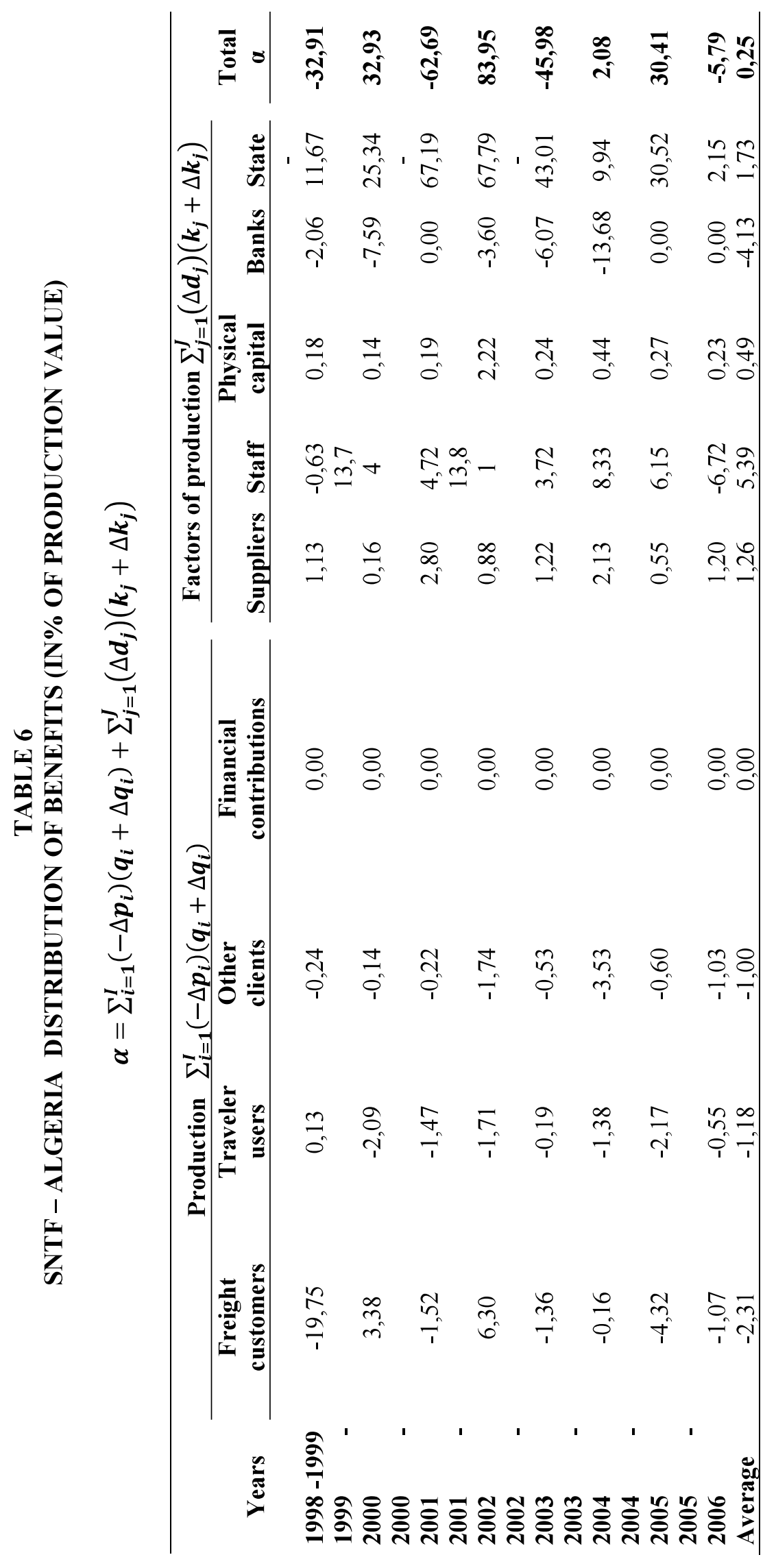

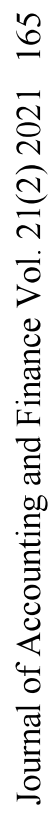

